\title{
ATTITUDES TOWARD EXTENSIVE READING AMONG ENGLISH TEACHERS OF SENIOR HIGH SCHOOLS
}

\author{
Ima Dwi Lailatul Firda, Utami Widiati, Ekaning Dewanti Laksmi, \& Nur Hayati \\ Universitas Negeri Malang, Jl. Semarang 5 Malang \\ e-mail: Imafirda75@gmail.com
}

\begin{abstract}
Attitudes Toward Extensive Reading Among English Teachers of Senior High Schools. This survey aims to investigate the attitudes of 32 English teachers of public senior high schools in a district in East Java Province, Indonesia, toward Extensive Reading (ER) as one of the ways of improving reading habit, covering the teachers' cognitive, behavioral, and affective attitudes. Questionnaires in the form of closed-ended and open-ended questions were used as the main instrument to collect the data, complemented with interviews with sampled teachers to gain more in-depth understanding of the phenomena under study. The results show that cognitively, most English teachers have positive cognitive attitudes, which implies good understanding of ER. The teachers' affective attitudes also reflect their eagerness to know more about implementing ER and to find ways of solving potential problems. However, in terms of behavioral attitudes, the data show that the teachers are still in doubt to conduct ER program due to several problems, such as time allotment, reading resources, students' motivation, curriculum and school programs, learning assessment, and school rules. The findings imply the need for policy makers at school and government's educational agencies, as well as experts in the field to help support the teachers in setting up ER program at schools by addressing the issues that teachers are concerned with.
\end{abstract}

Keywords: extensive reading, cognitive attitudes, behavioral attitudes, affective attitudes, literacy program

\begin{abstract}
Abstrak: Sikap Guru Bahasa Inggris Sekolah Menengah Atas Terhadap Membaca Ekstensif. Studi survei ini bertujuan untuk menyelidiki sikap (kognitif, konatif, dan afektif) dari 32 guru bahasa Inggris Sekolah Menengah Atas di salah satu kota di Provinsi Jawa Timur, Indonesia, terhadap membaca ekstensif sebagai salah satu cara untuk meningkatkan kebiasaan membaca. Kuesioner dalam bentuk pertanyaan tertutup dan terbuka digunakan sebagai instrumen utama untuk mengumpulkan data, serta dilengkapi dengan wawancara dengan guru sampel untuk mendapatkan pemahaman mendalam tentang fenomena yang diteliti. Hasil penelitian menunjukkan bahwa secara kognitif, sebagian besar guru bahasa Inggris memiliki sikap kognitif positif, yang menyiratkan pemahaman yang baik tentang membaca ekstensif. Sikap afektif guru juga mencerminkan keinginan mereka untuk mengetahui lebih banyak tentang penerapan membaca ekstensif dan untuk menemukan cara memecahkan masalah potensial. Namun, dalam hal sikap konatif, data menunjukkan bahwa guru masih ragu untuk melakukan program membaca ekstensif karena beberapa masalah, seperti alokasi waktu, sumber bacaan, motivasi siswa, kurikulum dan program sekolah, penilaian pembelajaran, dan peraturan sekolah. Hasil-hasil ini menyiratkan perlunya pembuat kebijakan di sekolah dan lembaga pendidikan pemerintah, serta para ahli di lapangan untuk membantu mendukung para guru dalam menyiapkan program membaca ekstensif di sekolahsekolah dengan menangani isu-isu yang berkaitan dengan guru.
\end{abstract}

Kata kunci: membaca ekstensif, sikap kognitif, sikap konatif, sikap afektif, program literasi

A number of studies have been conducted to demonstrate the role that extensive reading (ER) plays in language development and literacy. In the context of English language teaching, many studies have empirically proven positive results gained from
ER activities in relation to various areas in second or foreign language learning development, such as in reading skills (Hayashi, 1999; Meng, 2009), writing skills (Mermelstein, 2015), reading fluency (Taguchi, Takayasu-Maass, \& Gorsuch, 2004;), vo- 
cabulary acquisition (Kweon \& Kim, 2008; Pigada \& Schmitt, 2006; Senoo \& Yonemoto, 2014), grammatical mastery (Khansir \& Dehghani, 2015), lexical depth (Jafarpour, 2014), and positive attitudes (Judge, 2011; Yamashita, 2013).

With all such various merits, it seems questionable not to include ER as a teaching and learning program in English classrooms. However, as having been well noted by Macalister (2010), teachers' positive attitudes about the language learning benefits of ER do not necessarily interrelate with their willingness to incorporate ER activities into their classroom. Some possible reasons might be that language teachers feel unsettled to include ER time into their teaching plan (Herman, 2003 cited in Macalister, 2010), or they have a culturally different viewpoint regarding silent reading as one of the characteristics of ER implementation because in some cultures, silent reading might not be perceived as class learning (Prowse, 2002). Teachers' hesitation in conducting ER is also shown by Huang (2015). Another worth-noting point is related to how reading practices are held in Asian contexts. As Robb (2002) observes, in spite of the limited time, EFL classes in Asia are to focus on teaching all the four skills. This may result in limited reading time, particularly time for ER activities (Macalister, 2010). The exclusion of ER programs from language learning activities is likely to affect students' language development and literacy; they might not build up a good reading habit, nor may they be willing to read English books voluntarily. According to Asraf and Ahmad (2003), students need to be well situated to take up voluntary reading activities through a systemic reading program such as ER.

Based on the aforementioned research review, this present study aims to elicit teachers' attitudes toward ER programs. Ajzen (1988) states that attitude refers to being inclined to respond to an object, a person, an institution, or an event, either favorably or unfavorably. Attitudes according to Hogg and Vaughan (2014:151) are classified into three categories of cognitive, behavioral, and affective domains or the so-called three-component attitude model in which each attitude is made up of thoughts and ideas, a cluster of feelings, likes and dislikes, and behavioral intentions. Ajzen (1988) further explains that cognitive responses reflect perceptions of, and information about, the attitude object; behavioral responses reflect behavioral inclinations, intentions, commitments, and actions with respect to the attitude object. Therefore, since teachers have a vital role in classroom practice, investigating their attitudes is important in the promotion of ER in EFL context like Indonesia.

Inspired by Macalister's study (2010) which investigated such attitudinal issues in the context of higher education, this study is projected to further explore a rather different focus of attention by eliciting high school teachers' attitudes in the Indonesian context toward ER programs. This study bears a similar concern to that of Macalister's (2010), addressing a question raised by Renandya (2007): Why isn't everybody doing ER even though it is beneficial for second or foreign language development? In other words, this present study attempts to elicit teachers' attitudes toward ER programs on three main components of cognitive, behavioral, and affective domains, especially in Indonesia where English is taught as a foreign language. This attempt is, in fact, also relevant to School Literacy Program (SLP) stipulated by the Indonesian government, which has been implemented in Indonesian high schools where the focus of this study was directed.

Indonesian government has launched SLP with the enforcement of the Regulation of the Minister of Education and Culture No. 23 of 2015, as an effort to develop Indonesian students' better literacy and to encourage lifelong learning through reading and writing activities. The main purposes of SLP are to contribute to the character building of Indonesian students through a number of literacy activities and to boost their reading habit and their love of reading. The program seems to be partly triggered by these reasons: Indonesia's being the second lowest rank of reading habit, as later revealed by a study conducted by Miller (2016), the demand of reading ability in the $21^{\text {st }}$ century, and the ineffective literacy learning process at schools.

The idea of SLP might be narrowly implemented by schools to utilizing reading resources in Indonesian. Therefore, this study is intended to obtain empirical data concerning how English teachers respond to this government policy. It aims to explore whether English teachers can take advantages of SLP by implementing ER activities in their teaching and learning process of English. In other words, referring to the essential common features of both SLP and ER, this study is under the assumption that English teachers can positively contribute to the success of the implementation of SLP when they integrate ER activities in their teaching practice. However, teachers' good ER practice might be stimulated by good attitudes toward ER program. Therefore, it appears necessary to firstly find 
out English teachers' cognitive, behavioral, and affective attitudes toward ER.

\section{METHOD}

A survey research design by adapting survey stages in Creswell (2012) was employed in this study, involving ten public senior high schools in a district in East Java, Indonesia. Senior high schools were selected as the setting of the study because the English teaching at this level in Indonesia was directed more toward the development of informative literacy level, which appeared to be in line with the objective of this study. However, permission to carry out the study was granted by nine schools only, with a total of 35 English teachers in the schools. Out of the 35 English teachers, only 32 expressed willingness to participate in the study voluntarily.

Two instruments - questionnaires and interview - were used to collect the data. The questionnaires had adapted from Macalister (2010). The respondents were asked to answer Yes, Unsure, or No to ten closed-ended questions concerning their $\operatorname{cog}$ nitive, behavioral and affective attitudes to extensive reading. There are four questions related to cognitive attitudes, that is, knowledge of teaching reading, knowledge of ER, and beliefs about benefits of ER program. Four questions were about teachers' behavioral attitudes, which included beliefs in teaching reading, activities for developing reading for fun, integration of ER in teaching, and system for monitoring. The other two questions concerned the teachers' affective attitudes, involving obstacles and willingness in implementing ER. The questionnaires were then translated into Indonesian, and the Indonesian version was validated by an ELT expert and tried out to two English teachers from schools other than the ones involved in this study to ensure the internal validity of the questionnaires in exploring attitudes.

A follow-up interview was carried out to $20 \%$ of the 32 English teachers, that is, six teachers, due to practical considerations. The follow-up interview with the randomly-selected six teachers aimed to get more information related to the implementation of ER by referring to their responses to the questionnaires. Interview guides were developed to link the questions to the questionnaire items in addition to other relevant questions.

The teachers' responses to the questionnaires were calculated and then presented quantitatively in the form of percentages following Macalister (2010). Data from both the questionnaires and the followup interviews were further analyzed in terms of the teachers' cognitive, behavioral, and affective attitudes.

\section{FINDINGS}

The following sub-sections present the results of the study regarding teachers' attitudes toward ER in three different domains: cognitive, behavioral and affective. The teachers' answers to the openended questions, which were then supported by the interviews, provide more meanings to their responses to the closed-ended questions which they answered with either yes, unsure, or no.

\section{Teachers' Cognitive Attitudes toward ER}

Teachers' cognitive attitudes toward ER were obtained from the teachers' answers to four questionnaire items as presented in Table 1. The data in the table show the number of teachers responding to each question by choosing either yes, unsure, or no.

Table 1 suggests that the teachers tend to have positive cognitive attitudes toward reading, as the majority $(87.5 \%)$ agreed with the statements in the questionnaire reflecting cognitive attitudes. Regarding questions number 1 and 2 on the teachers' familiarity with intensive and extensive reading, the data from the open-ended questions as well as from the interviews further illustrate the teachers' knowledge on the differences between both types of reading, as presented in Table 2.

\section{Table 1. Teachers' Cognitive Attitudes toward ER}

\begin{tabular}{|c|c|c|c|c|c|c|c|}
\hline No & Components & Yes & $\%$ & Unsure & $\%$ & No & $\%$ \\
\hline 1. & $\begin{array}{l}\text { Teaching reading consists of two types - intensive } \\
\text { and extensive readings. }\end{array}$ & 28 & $87.5 \%$ & 4 & $12.5 \%$ & 0 & $0 \%$ \\
\hline 2. & I know what ER is. & 28 & $87.5 \%$ & 4 & $13.5 \%$ & 0 & $0 \%$ \\
\hline 3. & $\begin{array}{l}\text { I believe that students can learn English through } \\
\text { reading for pleasure. }\end{array}$ & 27 & $84 \%$ & 5 & $16 \%$ & 0 & $0 \%$ \\
\hline \multirow[t]{2}{*}{4.} & $\begin{array}{l}\text { I believe that ER gives positive advantages toward } \\
\text { students' language acquisition. }\end{array}$ & 30 & $94 \%$ & 2 & $6 \%$ & 0 & $0 \%$ \\
\hline & Average & 28 & $87.5 \%$ & 4 & $12.5 \%$ & 0 & $0 \%$ \\
\hline
\end{tabular}


Table 2. Teachers' Knowledge on the Differences between Intensive and Extensive Reading

\begin{tabular}{ll}
\hline \multicolumn{1}{c}{ Intensive Reading (IR) } & \multicolumn{1}{c}{ Extensive Reading (ER) } \\
\hline - IR is reading in detail for specific learning purposes. & - ER is reading for enjoyment. \\
- IR is reading activity inside the classroom, the mate- & - ER is fast reading aimed at understanding the whole idea of the text. \\
rials of which come from the teacher.. & - ER is an activity of reading outside the class to build students' read- \\
- IR is reading activity conducted in sequence/ con- & ing habit. \\
tinuously/ intensively. & - ER is free reading which allows the students to read any books they \\
- IR is reading in detail to develop students' critical & like. \\
thinking. & - Materials in ER are based on the students' levels and interests. \\
- IR is focused on reading short texts. & - ER is an independent reading of the extent program from IR. \\
- IR is emphasized on understanding the text by & - ER is emphasized on the development of the language features. \\
means of reading comprehension exercises. & - ER is reading something in large amount. \\
\hline
\end{tabular}

The summary data in Table 2 reveal that most teachers knew well the definition of IR and ER. Most of them commented in a detailed way about the differences between IR and ER. After knowing the teachers' knowledge of what ER is, the next statement is about teachers' beliefs whether their students can learn English through reading for pleasure. The data in Table 1 show that there were 27 teachers $(84 \%)$ who agreed with this statement and five $(16 \%)$ who felt unsure.

The teachers cited various benefits gained from reading for pleasure, as revealed in their responses to the open-ended questions. These included students' acquiring new vocabulary and knowledge, building good atmosphere for reading, and increasing students' motivation as the materials used for ER should match students' interest and language ability. Other teachers stated that English can be learnt through reading for pleasure as the students read various authentic materials and be exposed to natural use of the language. Reading for pleasure can also compensate for the lack of time for reading in English in the classroom.

For the five teachers who were unsure whether reading for pleasure program can be used in learning English, they argued that not all students were, in fact, eager to read books. Thus, they thought that only motivated students can get the advantages of ER. One teacher mentioned that IR was more important in order to make students understand texts better. Additionally, there is one teacher who did not respond to this question.

Regarding the contribution of ER to students' language acquisition, Table 1 indicates that almost all teachers, that is, 30 out of 32 (94\%) believe ER gives positive effects on the students' language acquisition, such as, vocabulary enrichment, improved motivation or the love for reading, and new knowledge. They also believe that ER can develop good grammar since students absorb grammatical patterns more easily and subconsciously as they read a lot of materials of their level and interest and be exposed to the use of different grammatical structures. In addition, some of the teachers asserted that ER can increase the students' reading skill, build reading speed and fluency, and cultivate independent learning. Two teachers also mentioned the authenticity of the reading experience in ER as they tend to be engaged more in reading texts of real-life situations.

However, there are two teachers who felt unsure whether ER benefits students' language acquisition even though one of them states that the students can get new knowledge from ER, and the other states that the students will be more motivated in reading because the books are suitable with their interest.

Overall, the data presented in both Table 1 and Table 2 suggest the teachers' positive attitudes toward ER in terms of cognitive domain.

\section{Teachers' Behavioral Attitudes toward ER}

The findings on teachers' behavioral attitudes toward ER were obtained from their responses to four items in the questionnaire, as presented in Table 3 .

It can be seen from Table 3 that the teachers' behavioral attitudes toward ER tend to be moderately positive. However, it does not mean that these behavioral attitudes are influenced by the teachers' cognitive attitudes. From the explanation that the teachers described further in the open-ended questions, the cognitive attitude might be just one of the predicting factors to indicate whether positive behavioral attitudes are influenced by good knowledge or vice versa.

When asked whether they believed that their current teaching program for reading activities was as good as they could reasonably make it, 14 out of 32 teachers $(44 \%)$ indicated that their teaching program for reading activities was good. These are some of the techniques in teaching reading that the teachers usually implement: three-phase reading covering 
Table 3. Teachers' Behavioral Attitudes toward ER

\begin{tabular}{|c|c|c|c|c|c|c|c|}
\hline No & Components & Yes & $\%$ & Unsure & $\%$ & No & $\%$ \\
\hline 5. & $\begin{array}{l}\text { I believe that my current teaching program for read- } \\
\text { ing activity is about as good as I can reasonably } \\
\text { make it. }\end{array}$ & 14 & $44 \%$ & 15 & $47 \%$ & 3 & $9 \%$ \\
\hline 6. & I encourage my students to read for pleasure. & 24 & $75 \%$ & 6 & $19 \%$ & 2 & $6 \%$ \\
\hline 7. & $\begin{array}{l}\text { I include ER as part of my in-class teaching pro- } \\
\text { gram. }\end{array}$ & 19 & $63 \%$ & 8 & $25 \%$ & 5 & $16 \%$ \\
\hline \multirow[t]{2}{*}{8.} & I have a system for monitoring my students' reading. & 12 & $38 \%$ & 10 & $31 \%$ & 10 & $31 \%$ \\
\hline & Average & 17 & $53 \%$ & 10 & $31 \%$ & 5 & $16 \%$ \\
\hline
\end{tabular}

pre-activity for translating new vocabulary and whilst and post-activities for reading comprehension, scanning and skimming, jigsaw technique, and KWL (Know, What, Learn) technique.

In addition, 15 out of 32 teachers $(47 \%)$ felt unsure whether the technique they used in teaching reading was as good as they could make it. Most of them felt so because the students could not learn reading only through $I R$. In this case, they thought that both IR and ER are necessary. This group of teachers also admitted that they implemented skimming and scanning, three-phase technique, cooperative learning, and KWL. Finally, three teachers (9\%) stated that they did not purely use ER for the whole activity in teaching reading; instead, they combined ER with IR.

When asked whether they encouraged their students to read for pleasure, 24 out of 32 teachers (75\%) answered yes. Various ways of motivating the students to read for pleasure based on the teachers' responses in the questionnaire are described as follows.

1. Asking the students to retell the story that they have read outside the school using their own words.

2. Providing some time in the beginning of the lesson to find any stories they like by finding the books or browsing from the internet.

3. Asking the students to visit reading corner in which it facilitates them to read or browse any books from the internet

4. Providing up-to-date reading texts

5. Providing novels, comics, short stories with illustrations

6. Discussing some background information related to the reading text

7. Giving bonus score whenever the students read books

8. Asking students to share their reading in groups

Next, the six teachers (19\%) who gave unsure responses in their questionnaire stated that they wanted to encourage the students to read for pleasure, but they had not had a chance to do so. They commented further that most of their students did not like reading. Finally, of the two teachers who answered no to the statement about encouraging the students to read for pleasure, one reasoned that she rarely provided materials for this, whereas the other argued that there was no exact rule from the school to motivate the students to develop reading habit.

Referring to the statement about including ER as part of their in-class teaching program, 19 out of 32 teachers $(63 \%)$ indicated agreement. Some of the reasons for why they included ER are that ER can encourage students to have good reading habit; ER can give more extra learning process outside the class due to lack of time for English lesson; and ER is beneficial to help students understand texts better through more exposure. A couple of teachers gave two rather different reasons, that is, ER is used to implement the theory the teachers had gotten and ER helps teachers assess their students' reading.

Eight out of 32 teachers who felt unsure mentioned various reasons why they hesitated to conduct ER. Two of them stated that they wished their students liked reading. Some of them stated that ER was only implemented when the topic of the lesson needed extra books or texts to read, for example, when the topic of the lesson was about narrative texts. The other teachers asserted that since there were so many subjects taken by the students, it was hard for them to conduct ER because ER would add more burden on their students.

The data from the interviews reveal that the implementation of ER program by the teachers varies. Four teachers included ER as part of classroom practice; they included it when they taught particular topics in the syllabus which required more time for the students to read such as narrative texts or recount texts. In this case, the teachers usually used some of the time to insert ER, by asking the students to find their own stories. Two respondents as- 
Table 4. Teachers' Affective Attitudes toward ER

\begin{tabular}{|c|c|c|c|c|c|c|c|}
\hline No & Components & Yes & $\%$ & Unsure & $\%$ & No & $\%$ \\
\hline 1. & $\begin{array}{l}\text { I would like to include (more) ER as an in-class ac- } \\
\text { tivity but crowded teaching program might impede } \\
\text { the success of the ER program. }\end{array}$ & 17 & $53 \%$ & 9 & $28 \%$ & 6 & $19 \%$ \\
\hline \multirow[t]{2}{*}{2.} & $\begin{array}{l}\text { If I have good knowledge about ER, I would like to } \\
\text { implement it as part of my teaching program. }\end{array}$ & 21 & $66 \%$ & 10 & $31 \%$ & 1 & $3 \%$ \\
\hline & Average & 19 & $59 \%$ & 10 & $31 \%$ & 3 & $10 \%$ \\
\hline
\end{tabular}

serted that they integrated the ER program in the SLP where students had to read and brought English books by themselves every Wednesday. However, since SLP was handled by any teacher who taught in the first hour on that day, sometimes the English teachers did not have a chance to control whether the students read English books.

When asked whether they had a system for monitoring their students' reading, 12 teachers (38\%) confirmed that they did the monitoring by using portfolio, summarizing, or retelling. Ten teachers felt unsure, and the other ten did not have a monitoring system. Those who they felt unsure further explained that what they did was checked the students' understanding on the story by asking questions to few students directly such as what the students liked from the story, what they got from the story, etc.

In a nutshell, although the percentages of responses show that the teachers' behavioral attitudes toward ER tend to be moderately positive, in fact, most teachers only incorporate ER in particular topics in the syllabus that need additional time to read. Furthermore, most teachers are still reluctant in incorporating ER program as a regular program for the students to read English texts.

\section{Teachers' Affective Attitudes toward ER}

Findings on the teachers' affective attitudes toward ER were obtained from their responses to two questionnaire items as shown in Table 4.

Table 4 suggests that the teachers' affective attitudes toward ER tend to be positive in a way that they are interested to implement or continue to implement ER. The two statements, however, also indicated that the teachers might face issues concerning their crowded teaching program and inadequate knowledge of ER.

The first obstacle concerned the time. Most teachers complained about the time provided for English lessons. Although some of them agreed that ER should be conducted outside the class, they were still worried about burdening the students as they likely to get a lot of assignments from other subjects or school programs. Another obstacle was about the resources for ER. Most teachers commented that English books were expensive and the books provided at their schools were limited. Some teachers also mentioned students' motivation as one of the issues when conducting ER. Since, in fact, many their students had low motivation in reading, the teachers hesitated whether ER would work well if they had to implement it. Regarding activity and assessment in ER, some teachers were confused about what they should do to make ER more interesting rather than just asking their students to submit weekly portfolio.

The curriculum and school program was mentioned as another obstacle to conduct ER. Three teachers asserted that there is no exact rule that ER should be implemented for English subject. Then, with regard to school rule, in schools where homework was not allowed, the teachers believed that ER could be included into activities done at home.

The last questionnaire item asks whether the teachers will include ER if they have good knowledge about it. Many of them answered yes and provided several reasons for why they wanted to include ER, such as wanting to motivate their students to have good reading habit, to increase vocabulary, and to build good grammar. Therefore, good knowledge about ER should be promoted to the teachers to solve most obstacles faced by the teachers even when they know well what ER is.

\section{DISCUSSION}

The findings of this study indicate that most of the teachers know well what ER is and can tell the differences between IR and ER. This might be partly caused by the fact that Indonesian teachers are accustomed to implementing SLP launched by the Indonesian government which basically has the same purposes as ER. However, one teacher who was interviewed cannot distinguish well the differences between IR and ER as s/he said, "Extensive reading is reading in larger vocabulary and higher reading comprehension in wider texts followed by 
reading comprehension after the reading activity." Such understanding might be because the implementation of IR is generally more dominant than that of ER in the Indonesian teaching context,. In fact, it is important for teachers to know the differences between the two terms in order to achieve the objectives of teaching reading.

The findings also show that almost all of the teachers believe that many benefits will be gained through ER. Most teachers mentioned students' gaining new vocabulary as the benefit of ER, which is in line with what has been identified by Pigada and Schmitt (2006), Kweon and Kim (2008), and Senoo and Yonemoto (2014). The teachers also mentioned increased motivation or the love for reading, which is similar to the findings of the studies by Yamashita (2013) and Judge (2011), and getting new knowledge through reading as suggested by Meng (2009). These advantages of ER cited by the teachers are also in line with what Macalister (2010) found in his study. He states that gaining vocabulary is the most frequently mentioned advantage of ER, followed by other benefits such as learning grammar, establishing confidence, and building up the love for reading. Similarly, Hedgcock and Farris (2009) assert, that students benefit from ER program on some such aspects as improving their background knowledge, building vocabulary and grammar knowledge, and increasing confidence and motivation to read. In order to gain the benefits, some requirements need to be fulfilled. As suggested by Day (2011), ER should be conducted continuously; interesting materials should be provided; good monitoring system and clear loaning and returning the books should be available.

In addition, the actual implementation of ER program in classroom practice still depends on the syllabus made by the government. As stated by Huang (2015) in his study, the big reason for teachers to not include ER as the whole or part of their classroom program is the big demand for them to complete the syllabus. Hence, although the results of this study show that half of the teachers have implemented ER program, the actual implementation revealed during the interviews indicates that the teachers provide little proportion of time for ER program by integrating it into particular topics in the syllabus. One respondent has asserted this by stating

"It is almost impossible if I conduct extensive reading in my class because it is considered as a homework for them, so the sense of fun reading cannot be achieved due to that per- ception. So, if the topic of the lesson needs additional reading activity, I usually ask them to find their own reading stories and then ask them to make a poster consisting of picture series and just a little bit information about the picture, and moral values."

Another teacher mentions similar reasons regarding different activities in conducting ER as follows.

"It is a habitual agenda in my English class when the topic of the lesson is narrative text. I will ask the students to do group work and ask them to find their own story. After that I usually ask them directly in the class their general understanding about the story. So, finally, I ask the group to make a simple drama based on that story."

In fact, only one school under study has conducted ER program as a part of SLP by assigning the students to read English books once a week, while the rest of the schools do not really implement the ER program as a routine habit. Although SLP launched by the government is mostly obligatory in each school, not many English teachers are aware that they actually can take advantages of that program by facilitating their students with more English books or asking them to bring English books in order to include ER program as part of the obligatory school program. Renandya (2007) asserts that ER program is a supplementary class library scheme where the students are facilitated with enough time to have reading for fun based on their level and interest.

ER which is not fully implemented can affect the way teachers monitor their students in reading. Even the one school which had implemented ER program once a week still found difficulty monitoring the students' reading activities. The program conducted in the school where one of the respondents taught, was part of the SLP which is generally conducted in 15-20 minutes at the beginning of the lesson in the morning. All teachers of any subject who teach at that period have the responsibility to guide the students to read the books that the students have brought by themselves. The students have to make a portfolio consisting of summaries of the texts and the titles of the books. Therefore, even though SLP for reading English books was conducted once a week in the school, the real practices in the classroom do not work as originally designed because the job of any teacher of any subject is more on keeping the literacy program run 
than ensuring that students read English books; most non-English teachers who usually keep the literacy program at that time do not really matter on what the materials that the students bring. Lack of coordination between English teachers and other teachers of non-English subjects impedes the success of ER program designed by English teachers in the school. Related to this, Brown (2009) mentions that the main practical concerns regarding ER deal with cost, lack of time, monitoring students' reading, managing the library of books, guiding students to choose appropriate books, and getting students engaged in reading.

Afterwards, there are many ways for the English teachers to see the success of ER program. One teacher in the interview stated that he just asks questions directly to the students. This is likely to impacts on the students' perception that the reading activity is not assessed and considered less important although ER program is basically for reading for pleasure, as expressed below.

"Maybe I still cannot handle how to make them aware that reading is important. I mostly ask directly to the students what they can learn from the story, but not all students are covered in this process. So, they consider that this process may not be assessed and finally they are reluctant to read the book."

It can be interpreted that the teachers' positive attitudes toward ER in terms of their cognition is in contrast with their actual implementation of ER. Most teachers in the interview reveal that ER program is hard to promote due to students' lack of motivation in reading and inadequate time allotment for English subject. This is also in line with Chang and Renandya's finding (2017) in their study which shows that the biggest obstacle in implementing ER program faced by EFL teachers is the students' low motivation in reading. Related to the issue of students' motivation, it mostly occurs

\section{REFERENCES}

Ajzen, I. 1988. Attitudes, Personality, and Behavior. Maidenhead, Berkshire: Open University Educational Enterprises Limited.

Archer, A.V. 2012. Analyzing the Extensive Reading Approach: Benefits and Challenges in the Mexican Context. A Colombian Journal for Teachers of English, 9(12): 169-184. Retrieved on May, $4^{\text {th }}$ 2018, Available at https://files.eric.ed.gov/fulltext/EJ1128021.pdf.

Asraf, R.M., \& Ahmad I. S. 2003. Promoting English Language Development and the Reading Habit in some countries where reading is not the common habit. Anderson (in Archer, 2012) states that reading is not people's culture in many parts of the world. In other words, most English teachers in public senior high schools under study find it difficult to promote ER program to build the students' reading habit as basically most Indonesian students are not interested in reading. Moreover, the issue of time allotment for ER program where the teachers need more time for ER program is also found in Macalister's study (2010) which shows that teachers have already been pressured by full teaching programs.

\section{CONCLUSIONS AND SUGGESTIONS}

There are several conclusions that can be drawn from the study regarding the attitudes toward ER among English teachers in public senior high schools in Indonesia. Firstly, seen from cognitive responses, the teachers' attitudes toward ER tend to be very positive. The teachers involved in this study can explain well what ER is and what the benefits gained through ER program are. In terms of behavioral domain, the teachers' attitudes toward ER tend to be moderately positive. Though the teachers indicated some good knowledge of ER, they appeared to still be in doubt to conduct an ER program. The time they allotted for ER was limited compared to other activities in their classroom practice. Despite the apparent doubts, the teachers showed positive affective attitudes toward ER. These positive attitudes lead the teachers to want to know more about how to implement ER program well and to find ways to solve the challenges they might face.

The findings imply the need for policy makers at school and government's educational agencies, as well as experts in the field to help support the teachers in setting up ER program at schools by addressing the issues that teachers are concerned with.

Among Students in Rural Schools Through the Guided Extensive Reading Program. Reading in a Foreign Language, 15(2): 83-102. Retrieved on October 10, 2017, Available at http://nflrc.hawaii.edu/rfl/October2003/mohdasraf/mohdasraf. html.

Brown, D. 2009. Why and How Textbooks should encourage Extensive Reading. ELT Journal, 63(3): 238-245. Retrieved on February, $5^{\text {th }} 2018$. Available at http://citeseerx.ist.psu.edu/viewdoc/download?doi=10.1.1.536.9008\&rep=rep1\&type =pdf. 
Chang, A.C., \& Renandya, W.A. 2017. Current Practice of Extensive Reading in Asia: Teachers' Perceptions. The Reading Matrix: An International Online Journal, 17(1): 40-58. Retrieved on January, $1^{\text {st }} 2018$. Available at http://www.readingmatrix.com/files/16-4vj138u3.pdf.

Creswell, J. 2012. Educational Research: Planning, Conducting and Evaluating Quantitative and Qualitative Research 4th Eds. Boston: MA Pearson.

Day, R.R, Bassett, J, Bowler, B, Parminter, S, \& Bullerd, N. 2011. Bringing Extensive Reading into the Classroom. New York: Oxford University Press.

Hayashi, K. 1999. Reading Strategies and Extensive Reading in EFL classes. RELC Journal, 30(2): 114-132.

Hedgcock, J.S \& Ferris, D.R. 2009. Teaching Readers of English Students, Texts, and Contexts. New York: Routledge.

Hogg, M.A., \& Vaughan, G.M. 2014. Social Psychology 7th Eds. Harlow: Pearson Education Limited.

Jafarpour, M. 2014. The Effect of Incorporating the Extensive Reading Approach into Vocabulary Instruction on Learners' Lexical Depth in an EFL Context. Advances in Language and Literary Studies, 5(3): 162-169. Retrieved on October 09, 2017, Available at http://dx.doi.org/10.7575/ aiac.alls.v.5n.3p.162.

Judge, P.B. 2011. Driven to Read: Enthusiastic Readers in a Japanese High School's Extensive Reading Program. Reading in a Foreign Language, 23(2): 161-186.

Khansir, A.A., \& Dehghani, N. 2015. The Impact of Extensive Reading on Grammatical Mastery of Iranian EFL learners. Theory and Practice in Language Studies, 5(7): 1501-1507. Retrieved on October 16, 2017, Available at http://dx.doi.org/ 10.17507/tpls.0507.25.

Kweon, S., \& Kim, H. 2008. Beyond Raw Frequency: Incidental Vocabulary Acquisition in Extensive Reading. Reading in a Foreign Language, 20(2): 191-215.

Macalister, J. 2010. Investigating Teacher Attitudes to Extensive Reading Practices in Higher Education: Why isn't everyone doing it? RELC Journal, 41(1): 59-75.
Meng, F. 2009. Developing Students' Reading Ability through Extensive Reading. English Language Teaching, 2(2): 132-137. Retrieved on November 1, 2017, Available at www.ccsenet.org/journal. html.

Mermelstein, A.D. 2015. Improving EFL Learners' Writing through Enhanced Extensive Reading. Reading in a Foreign Language, 27(2): 182-198.

Miller, J.W. 2016. World's Most Literate Nations Ranked. (Online) Retrieved on February 28, 2018, Available at https://webcapp.ccsu.edu/?news= $1767 \&$ data.

Minister of Education and Culture. 2015. Regulation of the Minister of Education and Culture No. 23 of 2015 about Character Building. Jakarta.

Pigada, M., \& Schmitt, N. 2006. Vocabulary Acquisition from Extensive Reading: A case study. Reading in a Foreign Language, 18(1): 1-28.

Prowse, P. 2002. Top Ten Principles for Teaching Extensive Reading - a Response. Reading in a Foreign Language, 14(2): 142-45. Retrieved October 9, 2017, Available at http://nflrc.hawaii.edu/ rfl/October2002/discussion/prowse.pdf.

Renandya, W.A. 2007.The Power of Extensive Reading. RELC Journal, 38(2): 133-149. Retrieved November 1, 2017 from http://RELC.sagepub.com.

Robb, T. 2002. Extensive Reading in an Asian Contextan Alternative View. Reading in a Foreign Language, 14(2): 146-147. Retrieved on October 25, 2017, Available at http://nflrc.hawaii.edu/rfl/October2002/discussion/robb.pdf.

Senoo, Y., \& Yonemoto, K. 2014. Vocabulary Learning through Extensive Reading: A Case Study. The Canadian Journal of Applied Linguistics, 17(2): 122.

Taguchi, E., Takayasu-Maass, M., \& Gorsuch, G.J. 2004. Developing Reading Fluency in EFL: How Assisted Repeated Reading and Extensive Reading Affect Fluency Development. Reading in a Foreign Language, 16(2): 70-96.

Yamashita, J. 2013. Effects of Extensive Reading on Reading Attitudes in a Foreign Language. Reading in a Foreign Language, 25(2): 248-263. Retrieved on November 1, 2017,Available at http:// www.nflrc.hawaii.edu/rfl/October2013/articles/yamashita.pdf. 